\title{
Aplikasi Ethephon dan Stiker Pascapanen untuk Perbaikan Kualitas Buah Jeruk Siam Garut (Citrus nobilis Lour)
}

\author{
Ethephon and Postharvest Sticker Applications for Quality Improvement \\ of Tangerine Fruit (Citrus nobilis Lour)
}

\author{
Metta Gitania Lieka ${ }^{1}$, Roedhy Poerwanto ${ }^{1,2 *}$ dan Darda Efendi ${ }^{1,2}$ \\ ${ }^{1}$ Departemen Agronomi dan Hortikultura, Fakultas Pertanian, Institut Pertanian Bogor (Bogor Agricultural University), \\ Jalan Meranti, Kampus IPB Darmaga, Bogor16680, Indonesia. \\ 2Pusat Kajian Hortikultura Tropika, Lembaga Penelitian dan Pengabdian kepada Masyarakat Institut Pertanian Bogor, \\ Jl. Raya Pajajaran, Kampus IPB Baranangsiang, Bogor, Indonesia
}

Diterima 28 Mei 2018/Disetujui 11 Juni 2018

\begin{abstract}
Tangerine fruit is one of the fruit commodity favorited by Indonesian people. The main problem of local citrus is the color of its peel. Tangerine fruit's peel is yellowish green when physiologically ripe. Degreening is a technology that can help produce orange color on fruit peel by ethephon but ethephon can shorten shelf life. Postharvest sticker that contained sodium chloride is one of innovation that can extend the shelf life of fruits which produced by one of the companies in Malaysia. The used of postharvest sticker was expected can increase fruit shelf life. This study aimed to examine the effect of ethephon in degreening quickness and the used of postharvest sticker to increase the shelf life of siam tangerine fruit. This research used siam tangerine from Garut and conducted from August until September 2017 at Center for Tropical Horticulture Studies Bogor Agricultural University. The research used a Randomized Complete Block Design Group Factorial with ethephon (0 ppm and $1.000 \mathrm{ppm}$ ) as first factor and postharvest sticker (without and with postharvest sticker) as second factor. The result showed that the interaction between ethephon and postharvest sticker had no significant effect on visual, physical, and chemical quality. The application of 1.000 ppm ethephon could significantly speed up the degreening process on siam tangerine fruit till 10 days to get yellowish orange compared with fruit without ethephon application. The orange color on the fruit skin of ethephon treatment occured at age 11 days after treatment. The ethephon treatment had no significant effect on the chemical quality of the fruit. The ethephon treatment fruits began to decay at 9 days after treatment and the treated fruit without ethephon began to decay at 13 days after treatment. Postharvest sticker application had no significant effect on visual quality, physical quality, and chemical quality of siam tangerine fruit.
\end{abstract}

Keywords: citrus color index, decay, degreening, ethylene, sodium chloride

\section{ABSTRAK}

Jeruk siam Garut merupakan salah satu komoditas buah yang digemari oleh masyarakat Indonesia, tetapi memiliki daya saing yang rendah terhadap jeruk impor yaitu warna kulit masak cenderung hijau kekuningan. Teknologi degreening dengan menggunakan ethephon dan aplikasi stiker yang mengandung natrium klorida dapat diterapkan untuk menghasilkan kulit buah jeruk berwarna jingga dan memperlambat penuaan dan pembusukan buah. Penelitian ini bertujuan mengkaji pengaruh ethephon terhadap kecepatan degreening dan penggunaan stiker pascapanen terhadap perpanjangan umur simpan jeruk siam Garut. Penelitian ini dilaksanakan pada bulan Agustus sampai September 2017 di Laboratorium Pascapanen Pusat Kajian Hortikultura Tropika Institut Pertanian Bogor (PKHT IPB). Rancangan percobaan yang digunakan adalah Rancangan Kelompok Lengkap Teracak (RKLT) faktorial dengan ethephon (perlakuan ethephon dan perlakuan tanpa ethephon) sebagai faktor pertama dan stiker pascapanen (perlakuan stiker pascapanen dan perlakuan tanpa stiker pascapanen) sebagai faktor kedua. Hasil penelitian menunjukkan bahwa interaksi antara ethephon dengan stiker pascapanen tidak berpengaruh nyata terhadap kualitas visual, fisik, dan kimiawi buah jeruk. Aplikasi ethephon 1.000 ppm dapat mempercepat proses degreening hingga 10 hari, dibandingkan perlakuan tanpa ethephon. Warna jingga pada kulit buah perlakuan ethephon terjadi pada umur 11 HSP, meskipun tidak berpengaruh nyata terhadap kualitas kimiawi buah. Buah perlakuan ethephon mulai mengalami pembusukan pada umur 9 HSP dan buah perlakuan tanpa ethephon mulai mengalami pembusukan pada umur 13 HSP. Aplikasi stiker pascapanen tidak berpengaruh nyata terhadap kualitas visual, fisik, dan kimiawi buah jeruk siam Garut.

Kata kunci: citrus color index, etilen, natrium klorida, pembusukan, penguningan

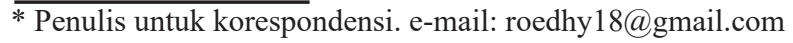




\section{PENDAHULUAN}

Jeruk merupakan salah satu buah yang digemari masyarakat Indonesia baik sebagai buah segar maupun olahan. Konsumsi jeruk tahun 2015 sebesar 2,73 kg kap ${ }^{-1}$ tahun $^{-1}$ atau sebesar 696.759 ton setelah dikalikan dengan jumlah penduduk. Konsumsi jeruk untuk rumah tangga diproyeksikan meningkat selama lima tahun ke depan (2015-2019) dengan rata-rata 0,52\% (Kementan, 2015). Salah satu jenis jeruk yang digemari konsumen adalah jeruk siam Garut. Jeruk siam Garut memiliki warna kulit yang cenderung hijau kekuningan atau warna jingga yang tidak merata. Pembentukan warna jingga pada jeruk disebabkan oleh dua zat warna, yaitu $\beta$-citraurin yang membuat warna kulit jeruk menjadi kemerahan dan $\beta$-cryptoxanthin yang membuat warna kulit jeruk menjadi kuning. Kegagalan terbentuknya warna jingga pada kulit buah jeruk di Indonesia (daerah tropik) dikarenakan pada proses pembentukan pigmen $\beta$-citraurin dibutuhkan suhu rendah $\left(15-25{ }^{\circ} \mathrm{C}\right)$. Teknologi yang banyak dilakukan untuk meningkatkan warna kulit buah jeruk tropika adalah degreening (Jomori et al., 2010). Teknologi degreening pada buah jeruk dapat dibantu dengan aplikasi ethephon.

Ethephon adalah suatu larutan yang mengandung bahan aktif dichloroethylphosponic acid yang dapat menghasilkan etilen secara langsung pada jaringan tanaman (Arif et al., 2014). Senyawa ethephon yang dilarutkan di dalam air melepaskan etilen dalam larutan atau jaringan tanaman melalui proses reaksi hidrolisis pada $\mathrm{pH}$ netral (Lizawati, 2008). Penggunaan etilen sebagai zat perangsang metabolik untuk mencapai warna eksternal buah dipengaruhi oleh konsentrasi dan durasi pemaparan (Martinez et al., 2008). Durasi pemaparan yang tepat akan menghasilkan warna jingga seragam pada kulit buah (Sdiri et al., 2012). Aplikasi ethephon pada buah jeruk siam Garut diharapkan dapat memperbaiki warna kulit buah sehingga dapat bersaing dengan jeruk impor. Namun aplikasi ethephon juga dapat mempercepat penuaan buah jeruk sehingga daya simpan buah menjadi lebih pendek.

Salah satu inovasi untuk menjaga daya simpan buah adalah stiker pascapanen yang sudah beredar di Malaysia dengan merk dagang Stixfresh. Stixfresh merupakan sebuah stiker pascapanen yang mengandung bahan utama berupa natrium klorida (Stixfresh, 2017). Natrium klorida merupakan senyawa dengan tingkat osmotik tinggi yang dapat menyeimbangkan kadar air yang ada di dalam buah. Senyawa ini mampu memperpanjang umur simpan buah segar (Ding, 2015). Menurut Ding (2015), penggunaan stixfresh juga dapat mengurangi kejadian penyakit secara signifikan yang secara tidak langsung dapat memperpanjang umur simpan buah dan tidak mempengaruhi kualitas kimiawi buah mangga Chok Anan selama 8 hari penyimpanan. Penggunaan stiker ini dapat dilakukan pada jeruk yang diaplikasikan teknik degreening untuk tetap dapat menjaga daya simpan buah jeruk. Pada kesempatan ini akan dilakukan penelitian degreening dengan ethephon yang dikombinasikan dengan perlakuan stiker pascapanen. Penelitian ini bertujuan mengkaji pengaruh ethephon terhadap kecepatan degreening dan penggunaan stiker pascapanen terhadap perpanjangan umur simpan jeruk siam Garut.

\section{BAHAN DAN METODE}

Penelitian dilaksanakan di Laboratorium Pascapanen Pusat Kajian Hortikultura Tropika, Institut Pertanian Bogor pada bulan Agustus hingga September 2017. Bahan yang digunakan adalah buah jeruk siam Garut sebanyak 240 buah, ethephon dengan merk dagang Ichipon 480SL, stiker pascapanen dengan merk dagang Stixfresh, larutan amilum, indikator phenolphthalein, larutan $\mathrm{NaOH} 0.1 \mathrm{~N}$, larutan iodium $0.01 \mathrm{~N}$, dan aquades. Alat yang digunakan adalah kotak kardus untuk menyimpan jeruk, kontainer untuk merendam jeruk, timbangan analitik, alat pemeras jeruk, color reader Konika Minolta CR-10 untuk mengukur nilai L (kecerahan), a (perubahan warna hijau ke merah), dan b (perubahan warna biru ke kuning) pada permukaan kulit buah yang akan dikonversikan ke dalam skor warna kulit buah atau citrus color index (CCI), refraktometer untuk analisis PTT, alat titrasi untuk analisis TAT dan vitamin $\mathrm{C}$, alat laboratorium, dan kamera.

Rancangan percobaan yang digunakan dalam penelitian ini adalah rancangan kelompok lengkap teracak (RKLT) faktorial, yaitu faktor ethephon (perlakuan ethephon dan perlakuan tanpa ethephon) sebagai faktor pertama dan faktor stiker pascapanen (perlakuan stiker pascapanen dan perlakuan tanpa stiker pascapanen) sebagai faktor kedua. Penelitian ini terdiri dari 4 kombinasi perlakuan, yaitu perlakuan tanpa ethephon dan tanpa stiker pascapanen (kontrol), perlakuan tanpa ethephon dengan stiker pascapanen, perlakuan ethephon tanpa stiker pascapanen dan perlakuan ethephon dengan stiker pascapanen.Setiap perlakuan diulang sebanyak 4 kali sehingga terdapat 16 satuan percobaan. Setiap satuan percobaan menggunakan 15 buah jeruk sehingga total buah jeruk yang digunakan sebanyak 240 buah. Pengamatan destruktif menggunakan 160 buah dan pengamatan nondestruktif menggunakan 80 buah.

Penelitian diawali dengan pemanenan buah jeruk siam Garut yang sudah masak fisiologis (berumur \pm 28 minggu setelah antesis), penyortiran berdasarkan warna dan ukuran yang seragam (kulit buah berwarna hijau dengan bobot buah \pm 100 -150 gram), pencucian menggunakan spons halus, perendaman dalam larutan ethephon 1.000 ppm selama 1 menit untuk buah perlakuan ethephon, perendaman dalam air selama 1 menit untuk buah perlakuan tanpa ethephon, pemasangan stiker pascapanen yang berdiameter $2.5 \mathrm{~cm}$ (sesuai dengan perlakuan), penyimpanan, dan pengamatan. Pengamatan meliputi pengamatan nondestruktif yang dilakukan setiap 2 hari sekali dan pengamatan destruktif yang dilakukan setiap 3 hari sekali. Pengamatan non destruktif meliputi warna kulit buah, bobot buah, susut bobot buah, persentase buah busuk, persentase buah layak konsumsi, dan persentase buah layak pasar. Persentase buah busuk dihitung menggunakan rumus :

$$
\text { Buah busuk }(\%)=\frac{\sum \text { buah busuk }}{\sum \text { buah total }} \times 100 \%
$$


Persentase buah layak konsumsi dihitung menggunakan rumus :

Buah layak konsumsi $(\%)=\frac{\Sigma \text { buah layak konsumsi }}{\Sigma \text { buah total }} \times 100 \%$

Persentase buah layak konsumsi dihitung menggunakan rumus :

Buah layak pasar $(\%)=\frac{\Sigma \text { buah layak pasar }}{\Sigma \text { buah total }} * 100 \%$

Pengamatan destruktif meliputi nilai padatan terlarut total (PTT), total asam tertitrasi (TAT), rasio PTT:TAT dan vitamin $\mathrm{C}$. Nilaicitrus color index(CCI) dihitung dengan rumus ; nilai ${ }^{\circ}$ hue dengan rumus ; nilai TAT dengan rumus ; dan vitamin $\mathrm{C}$ dengan rumus : $(\mathrm{ml} \mathrm{NaOH} \times \mathrm{N}$ NaoH $\mathrm{x}$ Fp x $64 \mathrm{mg} \mathrm{sampel}^{-1}$ ) x 100 dan vitamin $\mathrm{C}$ dengan rumus : (ml iod x $0.88 \times$ Fp/g sampel) x 100. Data yang diperoleh telah dianalisis menggunakan uji F pada taraf $\alpha 5 \%$ dan diuji lanjut dengan metode Duncan Multiple Range Test (DMRT) pada taraf $\alpha 5 \%$ untuk pengaruh nyata dan pada taraf $1 \%$ untuk pengaruh sangat nyata.

\section{HASIL DAN PEMBAHASAN}

\section{Kondisi Umum Buah}

Penyimpanan buah jeruk siam Garut dilakukan di dalam ruangan bersuhu sekitar $20{ }^{\circ} \mathrm{C}-26{ }^{\circ} \mathrm{C}$ dengan kelembaban berkisar antara 40\% - 56\% dengan jarak kurang lebih 1 m-1.5 m antar perlakuan. Rekapitulasi hasil analisis sidik ragam peubah visual, fisik, dan kandungan kimia buah jeruk siam Garut dapat dilihat pada Tabel 1 dan Tabel 2. Interaksi antara ethephon dengan stiker pascapanen tidak nyata dalam mempengaruhi kualitas visual, kualitas fisik, dan kualitas kimiawi buah jeruk siam Garut. Berdasarkan Tabel 1, perlakuan ethephon berpengaruh sangat nyata terhadap perubahan warna kulit buah jeruk siam Garut pada umur 3 HSP-21 HSP. Susut bobot buah perlakuan ethephon berbeda nyata terhadap buah perlakuan tanpa ethephon pada umur 5 HSP-15 HSP dan sangat nyata pada umur 19 HSP-21 HSP. Persentase buah busuk sangat nyata dipengaruhi oleh perlakuan ethephon pada umur 9 HSP21 HSP. Pembusukan buah pada penelitian ini disebabkan oleh beberapa faktor, yaitu senesen, cendawan, dan lalat buah (Gambar 1). Pengaruh stiker pascapanen terhadap kualitas visual, fisik, dan kimiawi buah jeruk siam Garut tidak terlihat secara nyata. Hal ini diduga disebabkan oleh jarak penyimpanan antara buah perlakuan stiker pascapanen dengan buah perlakuan tanpa stiker pascapanen terlalu dekat (1-1.5 meter) dibandingkan dengan jarak yang dianjurkan, yaitu \pm 5 kaki atau \pm 2.45 meter.

Berdasarkan Tabel 2, kandungan padatan terlarut total (PTT), total asam tertitrasi (TAT), dan vitamin C buah jeruk siam Garut tidak nyata dipengaruhi oleh perlakuan ethephon. Rasio PTT:TAT buah jeruk siam Garut nyata dipengaruhi perlakuan ethephon hanya pada umur 19 HSP.

Tabel 1. Rekapitulasi hasil analisis sidik ragam perlakuan ethephon dan stiker pascapanen terhadap kualitas visual dan kualitas fisik buah jeruk siam Garut

\begin{tabular}{|c|c|c|c|c|c|c|c|c|c|c|c|c|}
\hline \multirow{2}{*}{ Peubah } & \multirow{2}{*}{ Perlakuan } & \multicolumn{11}{|c|}{ Hari setelah perlakuan (HSP) } \\
\hline & & 0 & 3 & 5 & 7 & 9 & 11 & 13 & 15 & 17 & 19 & 21 \\
\hline \multirow[t]{4}{*}{ Citrus color index } & Ethephon & tn & $* *$ & $* *$ & $* *$ & $* *$ & $* *$ & $* *$ & $* *$ & $* *$ & $* *$ & $* *$ \\
\hline & Stiker pascapanen & tn & tn & tn & tn & tn & tn & tn & tn & tn & tn & tn \\
\hline & Ethephon $\times$ stiker pascapanen & $\operatorname{tn}$ & tn & tn & tn & tn & $\operatorname{tn}$ & tn & tn & tn & tn & tn \\
\hline & KK $(\%)$ & $1.4^{\mathrm{a}}$ & 29.9 & 19.9 & 15.8 & 15.2 & 12.2 & 17.4 & 11.7 & 19.7 & 16.1 & 14.8 \\
\hline \multirow[t]{4}{*}{ ohue } & Ethephon & tn & $* *$ & $* *$ & $* *$ & $* *$ & $* *$ & $* *$ & $* *$ & $* *$ & $* *$ & $* *$ \\
\hline & Stiker pascapanen & tn & th & tn & tn & th & tn & tn & th & tn & tn & th \\
\hline & Ethephon $\times$ stiker pascapanen & $\operatorname{tn}$ & $*$ & $\operatorname{tn}$ & tn & $\operatorname{tn}$ & $\operatorname{tn}$ & tn & tn & tn & tn & tn \\
\hline & KK $(\%)$ & 0.7 & 1.2 & 1.6 & 1.7 & 2.0 & 1.8 & 2.2 & 1.8 & 2.1 & 2.9 & 3.0 \\
\hline \multirow[t]{4}{*}{ Susut bobot (\%) } & Ethephon & - & tn & $*$ & $*$ & $*$ & * & $*$ & * & tn & $* *$ & $* *$ \\
\hline & Stiker pascapanen & & tn & $\operatorname{tn}$ & $\operatorname{tn}$ & $\operatorname{tn}$ & $\operatorname{tn}$ & $\operatorname{tn}$ & $\operatorname{tn}$ & tn & tn & $\operatorname{tn}$ \\
\hline & Ethephon $\times$ stiker pascapanen & - & $\operatorname{tn}$ & tn & tn & tn & tn & tn & tn & tn & tn & tn \\
\hline & $\mathrm{KK}(\%)$ & - & $0^{\mathrm{b}}$ & $6.8^{\mathrm{b}}$ & 26.3 & 21.3 & 17.4 & 14.5 & 12.2 & 10.5 & 14.2 & 11.9 \\
\hline \multirow[t]{4}{*}{ Buah busuk (\%) } & Ethephon & $\operatorname{tn}$ & tn & tn & tn & $* *$ & $* *$ & $* *$ & $* *$ & $* *$ & $* *$ & $* *$ \\
\hline & Stiker pascapanen & tn & tn & tn & tn & tn & tn & tn & $\operatorname{tn}$ & tn & $\operatorname{tn}$ & $\operatorname{tn}$ \\
\hline & Ethephon $\times$ stiker pascapanen & tn & tn & tn & tn & tn & tn & tn & tn & tn & tn & tn \\
\hline & KK $(\%)$ & $0^{\mathrm{b}}$ & $0^{\mathrm{b}}$ & $0^{\mathrm{b}}$ & $0^{\mathrm{b}}$ & $4.8^{\mathrm{b}}$ & $4.8^{\mathrm{b}}$ & $5.6^{\mathrm{b}}$ & $8.8^{\mathrm{b}}$ & $9.5^{\mathrm{b}}$ & $10.1^{\mathrm{b}}$ & $11.3^{\mathrm{b}}$ \\
\hline
\end{tabular}

Keterangan : HSP (hari setelah perlakuan). Angka yang diikuti huruf a dan b berturut-turut merupakan hasil transformasi data ke $\sqrt{ }(" \mathrm{x}+10 ")$ dan $\sqrt{ }(" \mathrm{x}+0,5$ " $), \mathrm{KK}=$ koefisien keragaman; $\mathrm{tn}=$ tidak berpengaruh nyata pada $\alpha<5 \%$; * berpengaruh nyata pada $\alpha<5 \%$; dan $* *=$ berpengaruh sangat nyata pada $\alpha<1 \%$ 
Perlakuan stiker pascapanen tidak nyata mempengaruhi kualitas visual, kualitas fisik, dan kualitas kimiawi buah jeruk siam Garut.

\section{Kualitas Visual Buah}

Kualitas visual buah jeruk siam garut pada umur 21 HSP secara umum dapat terlihat pada Gambar 2 bahwa jeruk yang diaplikasikan teknik degreening ( $\mathrm{c}$ dan d) memperoleh kulit berwarna jingga dan buah jeruk tanpa aplikasi teknik degreening (a dan b) memperoleh kulit berwarna kuning yang tidak merata pada permukaannya. Ethephon sangat cepat diubah menjadi etilen dalam air, memiliki tingkat toksisitas yang sangat rendah sehingga residunya tidak membahayakan bagi manusia (Ridhyanty et al., 2015). Aplikasi etilen dapat menstimulasi pembentukan karotenoid seperti $\beta$-cryptoxanthin, $\beta$-citraurin dan violaxanthin. Warna kulit buah tampak jingga kekuningan disebabkan karena hancurnya klorofil dan terakumulasinya karotenoid pada kulit buah (Hasimi et al., 2016). Warna kuning pada kulit jeruk terbentuk oleh $\beta$-cryptoxanthin, sedangkan warna jingga adalah campuran antara $\beta$-cryptoxanthin dengan

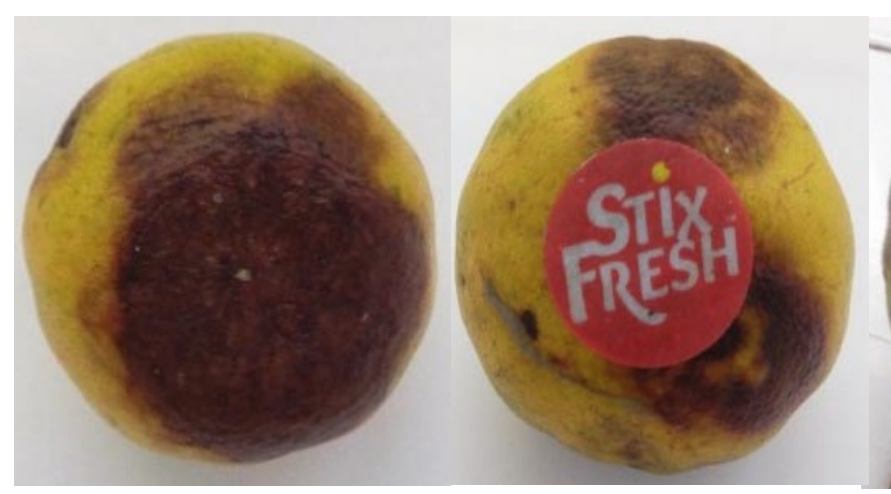

(a)

(b)

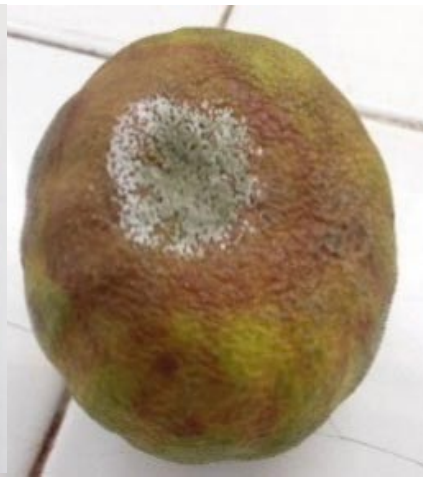

(c)

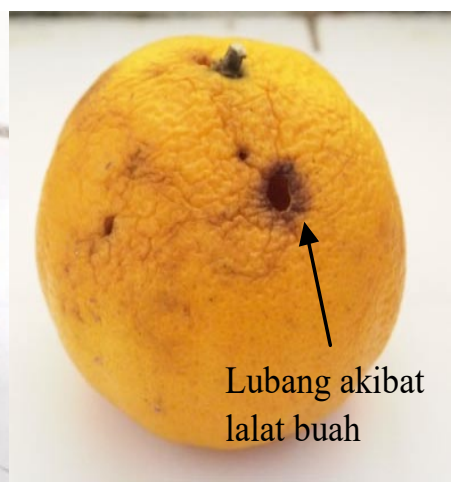

(d)

Gambar 1. Buah yang mengalami pembusukan akibat senesen (a dan b), cendawan (c), dan lalat buah (d)

Tabel 2. Rekapitulasi hasil analisis sidik ragam perlakuan ethephon dan stiker pascapanen terhadap kualitas kimiawi buah jeruk siam Garut

\begin{tabular}{|c|c|c|c|c|c|c|c|c|c|}
\hline \multirow{2}{*}{ Peubah } & \multirow{2}{*}{ Perlakuan } & \multicolumn{8}{|c|}{ Hari setelah perlakuan (HSP) } \\
\hline & & 1 & 4 & 7 & 10 & 13 & 16 & 19 & 22 \\
\hline \multirow[t]{4}{*}{ Padatan terlarut total (PTT) } & Ethephon & tn & $\operatorname{tn}$ & th & tn & tn & tn & $\operatorname{tn}$ & th \\
\hline & Stiker pascapanen & tn & tn & tn & tn & tn & tn & tn & tn \\
\hline & Ethephon $\times$ stiker pascapanen & tn & tn & tn & tn & tn & tn & tn & tn \\
\hline & KK $(\%)$ & 11.0 & 13.4 & 8.0 & 11.7 & 8.7 & 11.4 & 7.3 & 10.5 \\
\hline \multirow[t]{4}{*}{ Total asam tertitrasi (TAT) } & Ethephon & tn & tn & tn & tn & $\operatorname{tn}$ & tn & tn & tn \\
\hline & Stiker pascapanen & tn & $\operatorname{tn}$ & $\operatorname{tn}$ & $\operatorname{tn}$ & $\operatorname{tn}$ & tn & $\operatorname{tn}$ & tn \\
\hline & Ethephon $\times$ stiker pascapanen & th & tn & th & tn & th & tn & th & tn \\
\hline & $\mathrm{KK}(\%)$ & $14.2^{\mathrm{b}}$ & $12.5^{\mathrm{b}}$ & $11.8^{\mathrm{b}}$ & 29.7 & $14.7^{\mathrm{b}}$ & $11.4^{\mathrm{b}}$ & $8.4^{\mathrm{b}}$ & $21.4^{\mathrm{b}}$ \\
\hline \multirow[t]{4}{*}{ Rasio PTT:TAT } & Ethephon & tn & tn & tn & tn & tn & tn & $*$ & tn \\
\hline & Stiker pascapanen & tn & tn & tn & tn & tn & tn & tn & tn \\
\hline & Ethephon $\times$ stiker pascapanen & tn & th & tn & tn & tn & tn & tn & tn \\
\hline & KK $(\%)$ & $25.8^{\mathrm{b}}$ & $23.5^{\mathrm{b}}$ & $16.9^{\mathrm{b}}$ & 26.1 & $23.2^{\mathrm{b}}$ & $22.2^{\mathrm{b}}$ & 25.4 & $18.7^{\mathrm{b}}$ \\
\hline \multirow[t]{4}{*}{ Vitamin C } & Ethephon & tn & tn & tn & tn & tn & tn & tn & tn \\
\hline & Stiker pascapanen & tn & tn & tn & tn & tn & tn & tn & tn \\
\hline & Ethephon $\times$ stiker pascapanen & tn & $\operatorname{tn}$ & tn & tn & $\operatorname{tn}$ & tn & tn & $\operatorname{tn}$ \\
\hline & KK $(\%)$ & 6.9 & 11.5 & 6.6 & 16.4 & 9.6 & 15.9 & 13.0 & 8.5 \\
\hline
\end{tabular}

Keterangan : Angka yang diikuti huruf $\mathrm{b}$ merupakan hasil transformasi data $\mathrm{ke} \sqrt{ }(\mathrm{x}+0,5$ " ), $\mathrm{KK}=$ koefisien keragaman, $\mathrm{tn}=$ berpengaruh tidak nyata pada $\alpha<5 \%$, dan $*$ = berpengaruh nyata pada $\alpha<5 \%$ 
$\beta$-citraurin (Ma et al., 2013). Berdasarkan hasil pengamatan warna kulit buah jeruk siam Garut selama 21 hari diperoleh perubahan warna kulit jeruk dari hijau menuju jingga gelap dan nilai CCI berbanding terbalik dengan nilai derajat hue. Semakin tinggi nilai CCI, semakin rendah nilai derajat hue. Fase perubahan warna kulit buah jeruk siam Garut selama penyimpanan dapat dilihat pada Tabel 3.

Berdasarkan Tabel 4, nilai CCI dan derajat hue tidak nyata dipengaruhi oleh perlakuan stiker pascapanen namun sangat nyata dipengaruhi oleh perlakuan ethephon. Aplikasi ethephon $1.000 \mathrm{ppm}$ berpengaruh sangat nyata terhadap perubahan warna kulit buah jeruk siam Garut. Ethephon yang diaplikasikan pada buah non klimakterik (jeruk) bertujuan untuk menyeragamkan warna (degreening) sehingga dihasilkan buah dengan mutu yang seragam terutama dilihat dari segi warna dan penampakannya (Anna et al., 2012). Seluruh buah jeruk siam Garut pada umur 0 HSP memiliki kulit berwarna hijau. Buah jeruk perlakuan ethephon mengalami perubahan warna kulit lebih cepat 10 hari dibandingkan buah jeruk tanpa perlakuan ethephon untuk memperoleh warna kulit jingga kekuningan. Hal ini sesuai dengan pernyataan Hasimi et al. (2016) bahwa
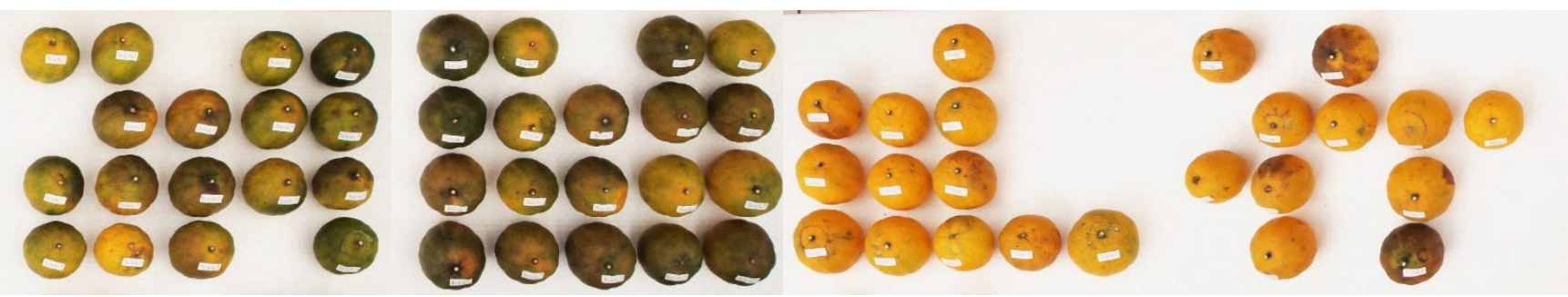

Gambar 2. Kondisi umum buah jeruk siam garut perlakuan tanpa ethephon dan tanpa stiker pascapanen (a), perlakuan tanpa ethephon dengan stiker pascapanen (b), perlakuan ethephon dan tanpa stiker pascapanen (c), dan perlakuan ethephon dengan stiker pascapanen (d) pada umur $21 \mathrm{HSP}$

Tabel 3. Hasil pengamatan kuantitatif warna kulit buah jeruk siam garut perlakuan ethephon pada setiap fase warna

\begin{tabular}{|c|c|c|c|c|}
\hline Gambar & Skor & Deskripsi warna & $\mathrm{CCI}$ & ${ }^{\circ}$ hue \\
\hline & 1 & Hijau & -0.4 & 91.2 \\
\hline & 2 & Hijau kekuningan & 1.5 & 86.5 \\
\hline & 3 & Kuning kehijauan & 3.6 & 81.5 \\
\hline & 4 & Jingga kekuningan & 5.9 & 73.9 \\
\hline & 5 & Jingga cerah & 7.5 & 70.1 \\
\hline & 6 & Jingga gelap & 10.3 & 64.9 \\
\hline
\end{tabular}


degreening menggunakan etilen dapat mempercepat perombakan klorofil dan mempercepat perkembangan warna buah dengan meningkatkan sintesis karotenoid.

Perlakuan ethephon menghasilkan warna jingga kekuningan pada umur 7 HSP, warna jingga pada umur 11 HSP, dan warna jingga gelap pada umur 17 HSP. Buah tanpa perlakuan ethephon hanya mampu mencapai warna kulit jingga kekuningan pada umur 21 HSP. Furqon (2017) menyatakan bahwa perlakuan degreening dapat meningkatkan warna kuning maupun jingga pada kulit buah jeruk siam garut dan buah jeruk siam Garut yang diberi perlakuan precooling $15^{\circ} \mathrm{C}$ sebelum aplikasi gas etilen 100 ppm memperoleh warna kulit buah jingga sempurna pada hari ke-13 setelah perlakuan. Hal ini menunjukkan bahwa pembentukkan warna jingga pada kulit buah jeruk siam Garut dengan aplikasi ethephon 1.000 ppm lebih cepat 2 hari dibandingkan buah jeruk siam garut dengan precooling $15{ }^{\circ} \mathrm{C}$ sebelum aplikasi gas etilen $100 \mathrm{ppm}$.

Nilai derajat hue pada buah jeruk perlakuan ethephon menunjukkan perbedaan yang sangat nyata terhadap buah jeruk tanpa perlakuan ethephon. Furqon (2017) menyatakan bahwa secara visual buah jeruk siam Garut yang memiliki nilai derajat hue rendah $( \pm 73,39)$ berwarna lebih kuning atau jingga dibandingkan dengan buah jeruk siam Garut yang memiliki nilai derajat hue tinggi $( \pm 90,87)$. Nilai derajat hue mengalami penurunan seiring semakin lamanya umur buah. Buah jeruk siam Garut perlakuan ethephon menunjukkan penurunan nilai derajat hue yang tinggi (91.2 pada umur 0 HSP menjadi 63.2 pada umur 21 HSP) dibandingkan buah tanpa perlakuan ethephon. Hal ini menunjukkan adanya perubahan yang cepat dari warna dominan hijau menuju warna dominan jingga pada buah yang diberi perlakuan ethephon. Perkembangan warna kulit buah jeruk perlakuan stiker pascapanen cenderung lebih lambat dibandingkan dengan buah jeruk perlakuan ethephon, yaitu dari warna hijau pada umur 0 HSP, hijau kekuningan pada umur 3-5 HSP, kuning kehijauan pada umur 7-9 HSP, jingga kekuningan pada umur 11-15 HSP, dan mencapai jingga pada umur 17 HSP. Nilai derajat hue tidak dipengaruhi oleh perlakuan stiker pascapanen secara nyata. Nilai derajat hue buah perlakuan tanpa stiker pascapanen pada umur 0 HSP sebesar 91.1 dan mengalami penurunan hingga 69.2 pada umur 21 HSP. Buah perlakuan stiker pascapanen menunjukkan nilai derajat hue sebesar 91.1 pada umur 0 HSP dan mengalami penurunan hingga 68.8 pada umur $21 \mathrm{HSP}$.

\section{Kualitas Fisik Buah}

Kualitas fisik buah jeruk siam Garut dapat diukur berdasarkan bobot buah, susut bobot buah, dan persentase buah busuk. Susut bobot buah pada perlakuan ethephon lebih rendah secara nyata dibandingkan pada buah perlakuan tanpa ethephon (Tabel 5). Namun demikian Mayuoni et al. (2011) menyatakan bahwa perlakuan degreening selain memperbaiki kualitas visual buah juga dapat memberikan efek yang buruk terhadap susut bobot buah.

Tingginya susut bobot buah jeruk perlakuan tanpa ethephon dibandingkan buah perlakuan ethephon diduga disebabkan oleh pengerasan kulit buah yang terjadi pada buah perlakuan tanpa ethephon. Anna et al. (2012) menyatakan bahwa buah yang diberi bahan perangsang pematangan ethephon menghasilkan kadar air yang lebih tinggi dibandingkan buah yang diberi bahan perangsang pematangan berupa etilen sehingga susut bobotnya lebih rendah. Efek ethephon yang dapat meningkatkan kadar air pada buah terung belanda juga diduga menjadi salah satu faktor tidak terjadinya pengerasan kulit buah jeruk siam garut perlakuan ethephon. Namun pengerasan kulit buah yang terjadi tidak mempengaruhi kualitas internal buah (Gambar 5). Qanytah (2004) menyatakan bahwa buah yang

Tabel 4. Pengaruh perlakuan ethephon dan stiker pascapanen terhadap kualitas visual buah

\begin{tabular}{|c|c|c|c|c|c|c|c|c|c|c|c|}
\hline \multirow[t]{2}{*}{ Perlakuan } & \multicolumn{11}{|c|}{ Umur (HSP) } \\
\hline & 0 & 3 & 5 & 7 & 9 & 11 & 13 & 15 & 17 & 19 & 21 \\
\hline \multicolumn{12}{|c|}{ Citrus color index (CCI) } \\
\hline Tanpa ethephon & -0.5 & $-0.3 b$ & $0.8 b$ & $1.5 b$ & $2.1 b$ & $2.9 \mathrm{~b}$ & $3.6 \mathrm{~b}$ & $4.5 b$ & $5.7 b$ & $5.8 \mathrm{~b}$ & $6.6 b$ \\
\hline Ethephon & -0.4 & $3.1 \mathrm{a}$ & $4.7 \mathrm{a}$ & $5.9 \mathrm{a}$ & $6.7 \mathrm{a}$ & $7.5 \mathrm{a}$ & $9.1 \mathrm{a}$ & $9.4 \mathrm{a}$ & $10.3 \mathrm{a}$ & $10.0 \mathrm{a}$ & $10.5 \mathrm{a}$ \\
\hline Tanpa stiker pascapanen & -0.5 & 1.4 & 2.7 & 3.6 & 4.6 & 5.2 & 6.5 & 7.0 & 8.2 & 7.6 & 8.3 \\
\hline Stiker pascapanen & -0.5 & 1.5 & 2.9 & 3.8 & 4.3 & 5.1 & 6.1 & 6.9 & 7.7 & 8.2 & 8.7 \\
\hline \multicolumn{12}{|c|}{${ }^{\circ}$ hue } \\
\hline Tanpa ethephon & 91 & $90.6 \mathrm{a}$ & $87.9 \mathrm{a}$ & $86.5 \mathrm{a}$ & $84.8 \mathrm{a}$ & $83.0 \mathrm{a}$ & $81.5 \mathrm{a}$ & $79.6 \mathrm{a}$ & $78.0 \mathrm{a}$ & $76.5 \mathrm{a}$ & $74.8 \mathrm{a}$ \\
\hline Ethephon & 91.2 & $81.7 \mathrm{~b}$ & $77.1 \mathrm{~b}$ & $73.9 b$ & $71.9 \mathrm{~b}$ & $70.1 b$ & $67.7 b$ & $66.5 b$ & $64.9 b$ & $64.1 b$ & $63.2 b$ \\
\hline Tanpa stiker pascapanen & 91.1 & 86.3 & 82.9 & 80.5 & 78.3 & 76.6 & 74.5 & 73.1 & 71.0 & 70.5 & 69.2 \\
\hline Stiker pascapanen & 91.1 & 85.9 & 82.2 & 79.9 & 78.4 & 76.5 & 74.7 & 73.0 & 71.8 & 70.1 & 68.8 \\
\hline
\end{tabular}

Keterangan : HSP (hari setelah perlakuan);c (pembuangan buah busuk). Nilai CCI $\leq-5$ (hijau gelap), $-5<\mathrm{CCI} \leq 0$ (hijau), $0<\mathrm{CCI} \leq 3$ (hijau kekuningan), $3<\mathrm{CCI} \leq 5$ (kuning kehijauan), $5<\mathrm{CCI} \leq 7$ (jingga kekuningan), $7<\mathrm{CCI} \leq 10$ (jingga) dan CCI $>10$ (jingga gelap). Angka-angka yang diikuti huruf yang berbeda pada kolom yang sama pada peelakuan etephon dan tanpa etephon menunjukkan perbedaan nyata berdasarkan hasil uji lanjut DMRT pada $\alpha<5 \%$ 
telah mentranspirasikan sebagian airnya akan mengeras. Pengerasan kulit buah terjadi karena sel-sel perikarp yang awalnya berbentuk bulat menjadi agak pipih akibat kehilangan turgor. Turgor sel ini menyebabkan sel-sel menciut sehingga ruang antar sel semakin menyempit dan pektin akan saling berikatan satu sama lain, serta integritas perikarp menjadi lebih resisten terhadap tekanan dan sulit dibuka. Laju transpirasi yang tinggi dapat disebabkan oleh kelembaban lingkungan sekitar yang rendah.

Etilen merupakan hormon tanaman yang dapat mempercepat terjadinya senesen. Daya simpan buah akan menurun dengan adanya pengaruh etilen (Setyadjit et al., 2012). Hal ini dapat terlihat pada persentase buah busuk (Tabel 5). Aplikasi ethephon 1.000 ppm berpengaruh sangat nyata dalam proses pembusukan buah jeruk siam Garut. Perlakuan ethephon mempercepat pembusukkan sekitar 4 hari dibandingkan perlakuan tanpa ethephon. Menurut Arzam (2015), perlakuan etilen pada perlakuan degreening pada suhu ruang menyebabkan tingkat pembusukan buah menjadi tinggi. Adanya proses respirasi dan transpirasi menyebabkan buah kehilangan air dan karbon. Hal ini disebabkan karena kerusakan dinding sel, pektin dan selulosa melalui metilesterasi pektin, poligalakturonasi dan selulosa (Sugianti et al., 2014). Berdasarkan Tabel 5, buah perlakuan ethephon lebih cepat 4 hari mengalami pembusukan dibandingkan dengan buah perlakuan tanpa ethephon. Buah perlakuan ethephon mengalami pembusukan pada umur 9 HSP dengan persentase buah busuk sebesar 12.5\% dan pada umur 21 HSP mencapai $42.5 \%$. Buah perlakuan tanpa ethephon mengalami pembusukan pada umur 13 HSP dengan persentase buah busuk sebesar $2.5 \%$ dan mencapai $10 \%$ pada umur 21 HSP.

Susut bobot buah jeruk siam Garut tidak dipengaruhi secara nyata oleh perlakuan stiker pascapanen. Stiker pascapanen yang digunakan mengandung natrium klorida. Berdasarkan penelitian yang dilakukan oleh Mizrahi (1982) pada buah tomat menunjukkan bahwa susut bobot cenderung meningkat seiring dengan peningkatan konsentrasi natrium klorida. Tingginya susut bobot akibat konsentrasi natrium klorida yang terlalu tinggi juga dibuktikan oleh Wirawan dan Anasta (2013) bahwa tingkat dehidrasi osmosis akan semakin tinggi seiring dengan meningkatnya konsentrasi larutan osmosis. Hal ini menyebabkan transfer air dari dalam buah ke luar buah semakin meningkat. Perlakuan stiker pascapanen tidak mempengaruhi persentase buah busuk secara nyata.Hal ini bertolak belakang dengan pernyataan Ding (2015) yang menyatakan bahwa stixfresh dapat memperpanjang masa simpan buah dengan mengurangi kejadian penyakit buah atau pembusukan. Adapun salah satu faktor yang diduga dapat menghambat keefektifan stiker pascapanen tersebut dalam memperpanjang umur simpan buah adalah stiker pascapanen yang digunakan sudah melewati batas umur optimumnya. Buah perlakuan stiker pascapanen memiliki persentase buah busuk sebesar $5 \%$ pada umur 9 HSP dan 25\% pada umur 21 HSP. Buah perlakuan tanpa stiker pascapanen mulai mengalami pembusukan pada umur 9 HSP dengan persentase buah busuk sebesar $7.5 \%$ dan mencapai $27.5 \%$ pada $21 \mathrm{HSP}$.

Tabel 5. Pengaruh perlakuan ethephon dan stiker pascapanen terhadap kualitas fisik buah

\begin{tabular}{|c|c|c|c|c|c|c|c|c|c|c|}
\hline \multirow{2}{*}{ Perlakuan } & \multicolumn{10}{|c|}{ Umur (HSP) } \\
\hline & 3 & 5 & 7 & 9 & 11 & 13 & 15 & 17 & $19^{c}$ & 21 \\
\hline \multicolumn{11}{|c|}{ Bobot (gram) } \\
\hline Tanpa ethephon & 113.9 & 106.8 & 102.3 & 99.2 & 96.6 & 94.4 & 92.4 & 90.1 & 88.9 & 87.3 \\
\hline Ethephon & 110.4 & 106.5 & 103.0 & 101.6 & 97.7 & 95.0 & 92.5 & 90.6 & 92.5 & 90.3 \\
\hline Tanpa stiker pascapanen & 109,5 & 104.9 & 101.1 & 99.4 & 95.1 & 92.6 & 90.3 & 88.3 & 88.8 & 86.8 \\
\hline Stiker pascapanen & 114.8 & 108.4 & 104.3 & 101.4 & 99.1 & 96.8 & 94.6 & 92.5 & 92.6 & 90.6 \\
\hline \multicolumn{11}{|c|}{ Susut bobot $(\%)$} \\
\hline Tanpa ethephon & 0.0 & $6.1 \mathrm{a}$ & $10.0 \mathrm{a}$ & $12.7 \mathrm{a}$ & $15.1 \mathrm{a}$ & $17.1 \mathrm{a}$ & $18.9 \mathrm{a}$ & 20.5 & $21.8 \mathrm{a}$ & $23.2 \mathrm{a}$ \\
\hline Ethephon & 0.0 & $3.5 b$ & $6.7 b$ & $9.3 b$ & $11.7 \mathrm{~b}$ & $14.1 \mathrm{~b}$ & $16.2 b$ & 18.4 & $16.0 \mathrm{~b}$ & $18.0 \mathrm{~b}$ \\
\hline Tanpa stiker pascapanen & 0.0 & 4.2 & 7.7 & 10.6 & 13.2 & 15.5 & 17.6 & 19.5 & 18.7 & 20.5 \\
\hline Stiker pascapanen & 0.0 & 5.4 & 9.0 & 11.4 & 13.6 & 15.6 & 17.5 & 19.4 & 19.1 & 20.8 \\
\hline \multicolumn{11}{|c|}{ Persentase buah busuk (\%) } \\
\hline Tanpa ethephon & 0.0 & 0.0 & 0.0 & $0.0 \mathrm{~b}$ & $0.0 \mathrm{~b}$ & $2.5 b$ & $2.5 b$ & $5.0 \mathrm{~b}$ & $10.0 \mathrm{~b}$ & $10.0 \mathrm{~b}$ \\
\hline Ethephon & 0.0 & 0.0 & 0.0 & $12.5 \mathrm{a}$ & $12.5 \mathrm{a}$ & $20.0 \mathrm{a}$ & $27.5 \mathrm{a}$ & $35.0 \mathrm{a}$ & $40.0 \mathrm{a}$ & $42.5 \mathrm{a}$ \\
\hline Tanpa stiker pascapanen & 0.0 & 0.0 & 0.0 & 7.5 & 7.5 & 12.5 & 15.0 & 20.0 & 27.5 & 27.5 \\
\hline Stiker pascapanen & 0.0 & 0.0 & 0.0 & 5.0 & 5.0 & 10.0 & 15.0 & 20.0 & 22.5 & 25.0 \\
\hline
\end{tabular}

Keterangan : HSP (hari setelah perlakuan, c (pembuangan buah busuk). Angka-angka yang diikuti huruf yang berbeda pada kolom yang sama pada perlakuan etephon dan tanpa etephon menunjukkan perbedaan nyata berdasarkan hasil uji lanjut DMRT pada $\alpha<5 \%$ 


\section{Kualitas Kimiawi Buah}

Kualitas kimiawi buah tidak dipengaruhi oleh perlakuan ethephon dan perlakuan stiker pascapanen (Tabel 6). Hal ini sesuai dengan Hasimi et al. (2016) bahwa degreening tidak memberikan pengaruh yang nyata terhadap kualitas internal buah jeruk siam Banyuwangi. Penelitian Ding (2015) menyatakan bahwa aplikasi stixfresh tidak memberikan pengaruh yang signifikan terhadap kandungan PTT dan TAT buah mangga Chok Anan.

Pemberian etilen dan bahan yang dapat mengeluarkan etilen dapat meningkatkan nilai total padatan terlarut (Anna et al., 2012). Perubahan PTT dapat dipengaruhi oleh rasio glukosa atau fruktosa dan asam organik selama proses penyimpanan (Javanmardi and Kubota, 2006). Padatan terlarut total (PTT) pada buah jeruk menunjukkan tingkat kemanisan (total gula) yang terkandung. Furqon (2017) menyatakan bahwa seiring lamanya waktu penyimpanan, kandungan padatan terlarut buah jeruk siam cenderung meningkat dan rasa buah akan semakin manis. Tabel 6 menunjukkan perubahan kandungan PTT buah pada semua perlakuan mengalami peningkatan. Kandungan PTT buah jeruk siam garut pada 1 HSP berkisar antara 9.4-9.8 ${ }^{\circ}$ brix dan meningkat hingga $10.4-11 .{ }^{\circ}$ brix pada umur 22 HSP.
Peranan etilen pada buah non klimakterik sangat kecil sehingga tidak mempengaruhi tingkat total asam buah terung belanda (Anna et al., 2012). Hal ini sesuai dengan hasil penelitian bahwa kandungan total asam tertitrasi (TAT) buah jeruk siam garut tidak dipengaruhi perlakuan ethephon secara nyata. Total asam tertitrasi (TAT) pada buah jeruk menunjukkan tingkat kemasaman buah. Kandungan TAT buah jeruk siam garut selama penyimpanan menunjukkan hasil yang fluktuatif (Tabel 6). Hal ini dapat disebabkan oleh perbedaan buah yang digunakan pada setiap pengujian. Furqon (2017) menyatakan bahwa kandungan TAT buah jeruk siam garut mengalami penurunan dari $0.63 \%-0.77 \%$ pada awal degreening menjadi $0.53 \%-0.64 \%$ pada 16 hari setelah degreening.

Rasio PTT:TAT menunjukkan tingkat kematangan buah. Hermansyah (2017) menyatakan bahwa semakin tinggi nilai rasio PTT:TAT maka semakin matang buah. Nilai rasio PTT:TAT buah jeruk siam Garut pada penelitian ini berfluktuatif karena buah yang digunakan dalam setiap kali pengujian berbeda (Tabel 6). Kandungan vitamin $\mathrm{C}$ buah jeruk siam Garut berkisar antara 34.5-44.5 mg per $100 \mathrm{~g}$ buah dan cenderung mengalami penurunan. Menurut Helmiyesi et al. (2008), penurunan kandungan vitamin $\mathrm{C}$ disebabkan oleh degradasi vitamin C. Beberapa

Tabel 6. Pengaruh perlakuan ethephon dan stiker pascapanen terhadap kualitas kimiawi buah

\begin{tabular}{|c|c|c|c|c|c|c|c|c|}
\hline \multirow{2}{*}{ Perlakuan } & \multicolumn{8}{|c|}{ Umur (HSP) } \\
\hline & 1 & 4 & 7 & 10 & 13 & 16 & 19 & 22 \\
\hline \multicolumn{9}{|c|}{ PTT ( ${ }^{\circ}$ brix $)$} \\
\hline Tanpa ethephon & 9.4 & 8.8 & 8.9 & 9.4 & 10.0 & 9.5 & 10.5 & 10.4 \\
\hline Ethephon & 9.8 & 9.8 & 9.3 & 9.6 & 10.8 & 10.1 & 10.9 & 11.1 \\
\hline Tanpa stiker pascapanen & 9.6 & 9.2 & 8.9 & 9.2 & 10.2 & 9.5 & 11.0 & 10.6 \\
\hline \multirow[t]{2}{*}{ Stiker pascapanen } & 9.7 & 9.4 & 9.3 & 9.8 & 10.6 & 10.1 & 10.3 & 10.9 \\
\hline & TAT $(\%)$ & & & & & & & \\
\hline Tanpa ethephon & 0.6 & 0.7 & 0.7 & 0.5 & 0.5 & 0.6 & 0.4 & 0.7 \\
\hline Ethephon & 0.6 & 0.6 & 0.7 & 0.5 & 0.7 & 0.7 & 0.6 & 0.9 \\
\hline Tanpa stiker pascapanen & 0.5 & 0.7 & 0.8 & 0.5 & 0.7 & 0.7 & 0.5 & 1.0 \\
\hline Stiker pascapanen & 0.7 & 0.6 & 0.6 & 0.5 & 0.5 & 0.6 & 0.4 & 0.6 \\
\hline \multicolumn{9}{|c|}{ Rasio PTT:TAT } \\
\hline Tanpa ethephon & 19.9 & 16.4 & 14.6 & 18.7 & 24.8 & 17.9 & $19.6 b$ & 20.6 \\
\hline Ethephon & 19.0 & 19.0 & 15.9 & 21.5 & 18.7 & 17.8 & $29.3 \mathrm{a}$ & 17.1 \\
\hline Tanpa stiker pascapanen & 21.3 & 16.3 & 12.6 & 20.3 & 21.0 & 15.8 & 23.8 & 15.6 \\
\hline Stiker pascapanen & 17.7 & 19.2 & 18.0 & 19.9 & 224 & 19.9 & 25.2 & 22.2 \\
\hline \multicolumn{9}{|c|}{ Vitamin C (mg.100 g buah $\left.{ }^{-1}\right)$} \\
\hline Tanpa ethephon & 41.5 & 35.6 & 38.0 & 41.6 & 37.5 & 36.1 & 41.2 & 41.2 \\
\hline Ethephon & 41,7 & 34.5 & 37.4 & 37.4 & 37.8 & 39.3 & 42.8 & 41.8 \\
\hline Tanpa stiker pascapanen & 41.4 & 34.6 & 37.5 & 38.7 & 37.6 & 37.7 & 44.4 & 41.1 \\
\hline Stiker pascapanen & 41.8 & 35.6 & 37.9 & 40.3 & 37.8 & 37.7 & 39.5 & 41.9 \\
\hline
\end{tabular}

Keterangan: HSP (hari setelah perlakuan), PTT (padatan terlarut total), TAT (total asam tertitrasi).Data telah dianalisis menggunakan uji $\mathrm{F}$ pada taraf $\alpha 5 \%$ dan menunjukkan hasil tidakberpengaruh nyata 
Lieka et al. / Comm. Horticulturae Journal 2(2):1-10

Tabel 7. Pengaruh perlakuan ethephon dan stiker pascapanen terhadap persentase buah layak konsumsi dan layak pasar

\begin{tabular}{|c|c|c|c|c|c|c|c|c|c|c|c|}
\hline \multirow{2}{*}{ Perlakuan } & \multicolumn{11}{|c|}{ Umur (HSP) } \\
\hline & 0 & 3 & 5 & 7 & 9 & 11 & 13 & 15 & 17 & $19^{\mathrm{c}}$ & 21 \\
\hline \multicolumn{12}{|c|}{ Persentase buah layak konsumsi (\%) } \\
\hline Tanpa ethephon & 100 & 100 & 100 & 100 & 100 & 100 & $97.5 \mathrm{a}$ & $97.5 \mathrm{a}$ & $95.0 \mathrm{a}$ & $92.5 \mathrm{a}$ & $92.5 \mathrm{a}$ \\
\hline Ethephon & 100 & 100 & 100 & 100 & 92.5 & 92.5 & $87.5 b$ & $82.5 b$ & $77.5 b$ & $75.0 \mathrm{~b}$ & $72.5 b$ \\
\hline Tanpa stiker pascapanen & 100 & 100 & 100 & 100 & 97.5 & 97.5 & 95.0 & 95.0 & $92.5 \mathrm{a}$ & 87.5 & 87.5 \\
\hline Stiker pascapanen & 100 & 100 & 100 & 100 & 95.0 & 95.0 & 90.0 & 85.0 & $80.0 \mathrm{~b}$ & 80.0 & 77.5 \\
\hline \multicolumn{12}{|c|}{ Persentase buah layak pasar $(\%)$} \\
\hline Tanpa ethephon & 100 & 95.0 & 92.5 & 80.0 & 65.0 & 42.5 & 32.5 & 17.5 & 15.0 & 15.0 & 15.0 \\
\hline Ethephon & 100 & 95.0 & 87.5 & 62.5 & 37.5 & 32.5 & 12.5 & 7.5 & 7.5 & 7.5 & 7.5 \\
\hline Tanpa stiker pascapanen & 100 & 97.5 & 90.0 & 82.5 & 62.5 & 42.5 & 27.5 & 15.0 & 12.5 & 12.5 & 12.5 \\
\hline Stiker pascapanen & 100 & 92.5 & 90.0 & 60.0 & 40.0 & 32.5 & 17.5 & 10.0 & 10.0 & 10.0 & 10.0 \\
\hline
\end{tabular}

Keterangan : HSP (hari setelah perlakuan), c (pembuangan buah busuk). Angka-angka yang diikuti huruf yang berbeda pada kolom yang sama menunjukkan perbedaan nyata berdasarkan hasil uji lanjut DMRT pada $\alpha<5 \%$.

faktor yang mempengaruhi degradasi vitamin $\mathrm{C}$ atau asam askorbat meliputi suhu, $\mathrm{pH}$, oksigen, enzim, katalis logam, konsentrasi awal asam askorbat dan perbandingan asam askorbat dengan asam dehidro askorbat (Hasmini, 2017).

\section{Jumlah Buah Layak Konsumsi dan Layak Pasar}

Buah jeruk siam Garut dalam penelitian ini mampu mempertahankan kualitas layak konsumsinya hingga umur 7 HSP. Pada umur 9 HSP, buah jeruk mulai mengalami penurunan jumlah buah layak konsumsi. Kriteria buah layak konsumsi adalah buah yang belum mengalami pembusukan. Perlakuan ethephon nyata berpengaruh terhadap jumlah buah layak konsumsi pada umur 13 HSP-21 HSP (Tabel 7). Perlakuan ethephon menunjukkan jumlah buah layak konsumsi yang lebih sedikit dibandingkan dengan perlakuan tanpa ethephon. Hal ini disebabkan aplikasi ethephon mempercepat senesen pada buah sehingga pembusukan juga cepat terjadi. Perlakuan stiker pascapanen menunjukkan jumlah buah layak konsumsi yang lebih rendah dibandingkan perlakuan tanpa stiker pascapanen.

Jumlah buah layak pasar tidak dipengaruhi secara nyata oleh perlakuan ethephon dan perlakuan stiker pascapanen (Tabel 7). Kriteria buah layak pasar pada penelitian ini adalah buah yang tidak mengalami pengerasan kulit, persentase keriput pada kulit buah $\leq 10 \%$, dan tidak mengalami pembusukan. Buah jeruk siam garut pada penelitian ini hanya mencapai sekitar umur 5-7 HSP untuk memenuhi kriteria layak pasar secara ekonomi. Hal ini disebabkan oleh persentase buah layak pasar sudah ada yang mencapai dibawah 50\% pada umur 9 HSP.

\section{KESIMPULAN}

Interaksi antara ethephon dengan stiker pascapanen tidak berpengaruh nyata terhadap kualitas visual, kualitas fisik, dan kualitas kimiawi buah jeruk siam Garut. Aplikasi ethephon 1.000 ppm dapat mempercepat proses degreening pada buah jeruk siam garut hingga 10 hari untuk memperoleh kulit berwarna jingga kekuningan dibandingkan buah perlakuan tanpa ethephon. Warna jingga pada kulit buah perlakuan ethephon terjadi pada umur 11 HSP. Perlakuan ethephon tidak berpengaruh nyata terhadap kualitas kimiawi buah. Buah perlakuan ethephon mulai mengalami pembusukan pada umur 9 HSP dan buah perlakuan tanpa ethephon mulai mengalami pembusukan pada umur 13 HSP. Aplikasi stiker pascapanen tidak berpengaruh nyata terhadap kualitas visual, kualitas fisik, dan kualitas kimiawi buah jeruk siam garut.

\section{DAFTAR PUSTAKA}

Anna, E.Y., E. Julianti, M. Nurminah. 2012. Pengaruh zat perangsang pematangan terhadap mutu buah terung belanda (Cyphomandra betacea). J. Rekayasa Pangan dan Pert 1(1): 27-34.

Arif, A.B., W, Diyono, E. Syaefullah, Suyanti, Setyadjit. 2014. Optimalisasi cara pemeraman buah cempedak (Artocarpus champeden). Informatika Pertanian 23 (1): 35-46.

Arzam, T.S. 2015. Pengembangan teknologi pembentukan pigmen jingga kulit buah jeruk. Skripsi. Institut Pertanian Bogor. Bogor.

Ding, P. 2015. Stixfresh reduce disease severity in riped Chok Anan mango fruit. Research. Universiti Putra Malaysia. Malaysia. 
Furqon, M.A. 2017. Aplikasi precooling dan suhu simpan setelah degreening untuk peningkatan warna jingga pada buah jeruk siam (Citrus nobilis). Skripsi. Institut Pertanian Bogor. Bogor.

Hasimi, N.R., R. Poerwanto, K. Suketi. 2016. Degreening buah jeruk siam (Citrus nobilis) pada beberapa konsentrasi dan durasi pemaparan etilen. J. Hort Indonesia 7(2):111-120.

Hasmini, N.R. 2017. Degreening dan pengaturan suhu simpan untuk meningkatkan kualitas buah jeruk siam (Citrus nobilis var Microcarpa) dataran rendah. Tesis. Institut Pertanian Bogor. Bogor.

Helmiyesi, R.B. Hastuti, E. Prihastanti. 2008. Pengaruh lama penyimpanan terhadap kadar gula dan vitamin $\mathrm{C}$ pada buah jeruk siam (Citrus nobilis var. Microcarpa). Buletin Anatomi dan Fisiologi 16(2):33-37.

Hermansyah, D. 2017. Perbandingan perkembangan dan kualitas buah tiga aksesi jeruk pamelo (Citrus maxima (Burm.) Merr.). Skripsi. Institut Pertanian Bogor. Bogor.

Javanmardi, J., C. Kubota. 2006. Variation of lycopene, antioxidant activity, total soluble solids and weight loss of tomato during postharvest storage. Postharvest Biology and Technology 41:151-155.

Jomori, M.L.L., I. Sestari, F.A.M. Terra, D.G. Chiou, R.A. Klauge. 2010. Degreening of 'Murcott' tangor with ethepon treatments. Proc. IV International Postharvest Symposium. Acta Hort. 877: 815-820.

[Kementan] Kementerian Pertanian. 2015. Outlook Jeruk. Pusat Data dan Sistem Informasi Pertanian, Jakarta.

Ma, G., L. Zhang, A. Matsuta, K. Matsutani, K. Yamawaki, M. Yahata, A.Wahyudi, R. Motohashi, M. Kato. 2013. Enzymatic formation of $\beta$-citraurin from $\beta$ - $\beta$ cryptoxanthin and zeaxanthin by carotenoid cleavage dioxygenase 4 in the flavedo of citrus fruit. Plant Physiol163:682-695.

Martinez-Javega, J.M., A. Monterde, P. Navarro, A. Salvador. 2008. Respons of new clementines to degreening treatment. Proc. Int. Soc. Citriculture 11: 1342-1346.

Mayuoni, L., Z. Tietel, B.S. Patil, R. Porat. 2011. Does ethylene degreening affect internal quality of citrus fruit? Postharvest Biology and Technology 62:5058.

Mizrahi, Y. 1982. Effect of salinity on tomato fruit ripening. Plant physiol 69:966-970.

Qanytah. 2004. Kajian perubahan mutu buah manggis (Garcinia mangostana L.) dengan perlakuan precooling dan penggunaan giberelin selama penyimpanan. Tesis. Insitut Pertanian Bogor. Bogor.

Ridhyanty, S.P., E. Julianti, L.M. Lubis. 2015. Pengaruh pemberian ethepon sebagai bahan perangsang pematangan terhadap mutu buah pisang barangan (Musa paradisiaca L). J. Rekayasa Pangan dan Pert 3(1):1-13.

Sdiri, S., P. Navarro, A. Monterde, J. Benabda, A. Salvador. 2012. New degreening treatments to improve the quality of citrus fruit combining different periods with and without ethylene exposure. J Postharvest Biol. Tech. 63: 25-32.

Setyadjit, E. Sukasih, A.W. Permana. 2012. Aplikasi 1-MCP dapat memperpanjang umur segar komoditas hortikultura. Buletin Teknologi Pascapanen Pertanian 8(1):27-34.

Stixfresh. 2017. Stixfresh features. www.stixfresh.com. [6 Agustus 2017].

Sugianti C., R. Hasbullah, Y.A. Purwanto, Y.A. Setyabudi. 2014. Kajian pengaruh iradiasi dosis $0.75 \mathrm{kGy}$ terhadap kerusakan dingin (chilling injury) pada mangga Gedong selama penyimpanan. Jurnal Teknik Pertanian Lampung 3(2):195-204.

Wirawan S.K., N. Anasta. 2013. Analisis permeasi air pada dehidrasi osmosis papaya (Carica papaya). Agritech 33(3):303-310. 